\title{
Is the Optimal Timing First Complete Remission for Autologous Stem Cell Transplantation in Patients with Peripheral T-Cell Lymphoma?
}

\author{
Periferik T Hücreli Lenfoma Hastarında Otolog Kök Hücre Nakli için Uygun Zamanlama Illk \\ Tam Remisyon mudur?
}

\author{
(D) Bahar UNCU ULU, (D) Derya ŞAHIN, (D) Tuğçe Nur YiĞENOĞLU, (D) Merih KIZIL ÇAKAR, (D) Mehmet Sinan DAL, (D) Fevzi ALTUNTAŞ \\ University of Health Sciences Turkey, Dr. Abdurrahman Yurtaslan Ankara Oncology Training and Research Hospital, Clinic of Hematology, Unit of Bone \\ Marrow Transplantation, Ankara, Turkey
}

\begin{abstract}
Aim: Outcome for most patients with peripheral T-cell lymphomas (PTCLs) is poor, with low response rates and short durations of remission. We aim to analyze the outcome of PTCL patients who underwent autologous stem cell transplantation (ASCT) at our center and we researched whether first complete remission (CR) was the optimal timing for ASCT in patients with PTCL.

Materials and Methods: The data of PTCL patients who underwent ASCT between January 2010 and December 2020 at our center were retrospectively analyzed.

Results: Twenty-five patients with PTCL underwent ASCT. The median ASCT age was 44 years (range: 19-68). 68\% of the patients were performed upfront ASCT after the first CR; 32\% of the patients underwent ASCT after relapse or refractory (R/R) disease. The median follow-up time from diagnosis was 40 months (13-144 months). The five-year PFS and OS were 50.8\% and 55.7\%, respectively. Five-year 0S was $82.4 \%$ in the up-front ASCT group, while the five-year OS was $15.6 \%$ in the $\mathrm{R} / \mathrm{R}$ patients $(\mathrm{p}=0.019)$. The median OS was 25 months [95\% confidence interval $(\mathrm{Cl})$ : $0-50.4$ ] in patients who had CR2, while it was 13 months $(95 \% \mathrm{Cl}: 0-35)$ in patients who had PR before ASCT ( $p=0.03$ ). According to subtypes of PTCL, OS and PFS were not statistically different in all groups ( $p=0.96$ and $p=0.79$, respectively).

Conclusion: Even the prognosis is poor in patients with PTCL, Overall survival was significantly longer among the upfront ASCT group. Patients should be consolidated with ASCT in the first CR, and relapse should not be waited to perform ASCT.

Keywords: Peripheral T cell lymphoma, PTCL, autologous stem cell transplantation, upfront ASCT

ÖZ

Amaç: Periferik T hücre lenfomalı (PTHL) çoğu hasta için sonuçlar, düşük yanıt oranları ve kısa remisyon süreleri ile kötü seyreder. Merkezimizde otolog kök hücre transplantasyonu (OKHN) yapılan PTHL hastalarının sonuçlarının analizini ve PTHL'li hastalarda OKHN için ilk tam remisyonun (TR) optimal zamanlama olup olmadığını araştırmayı amaçladık.

Gereç ve Yöntem: Merkezimizde Ocak 2010 ile Aralık 2020 arasında OKHN uygulanan PTHL hastalarının verileri geriye dönük olarak incelendi.

Bulgular: PTHL'li 25 hastaya OKHN uygulandı. Ortanca OKHN yaşı 44 (19-68) yıl olarak saptandı. Hastaların \%68'ine ilk TR'den sonra upfront OKHN yapııırken, \%32'sine relaps veya refrakter (R/R) hastalıktan sonra OKHN yapıldı. Tanıdan itibaren ortanca takip süresi 40 aydı (13-144 ay). Beş yılık progresyonsuz sağkalım (PS) ve toplam sağkalım (TS) sırasıyla \%50,8 ve \%55,7 idi. Beş yıllık TS upfront OKHN grubunda \%82,4 iken, R/R hastalarda \%15,6 idi $(p=0,019)$. OKHN öncesi TR2'de olan hastalarda ortanca TS 25 ay [\%95 güven aralığı (GA): 0-50,4] iken, OKHN öncesi kısmi yanıtı olan hastalarda 13 ay (\%95 GA: 0-35) idi $(p=0,03)$. PTHL alt tiplerine göre TS ve PS tüm gruplarda istatistiksel olarak farklı saptanmadı (sırasıyla $p=0,96$ ve $p=0,79)$.
\end{abstract}

Address for Correspondence: Bahar UNCU ULU MD, University of Health Sciences Turkey, Dr. Abdurrahman Yurtaslan Ankara Oncology Training and Research Hospital, Clinic of Hematology, Unit of Bone Marrow Transplantation, Ankara, Turkey

Phone.: +90 5428334430 E-mail: baharuncu@gmail.com ORCID ID: orcid.org/0000-0002-6230-9519

Received: 01.03.2021 Accepted: 21.04.2021 
Sonuç: PTHL hastalarında prognoz kötü olsa dahi, TS, upfront OKHN yapılan grupta önemli oranda daha uzun saptandı. Hastalar ilk TR'de OKHN ile konsolide edilmeli ve OKHN yapmak için relaps beklenmemelidir.

Anahtar Kelimeler: Periferik T hücreli lenfoma, PTHL, otolog kök hücre nakli, upfront OKHN

\section{INTRODUCTION}

The peripheral $\mathrm{T}$ cell lymphomas (PTCLs) represent a heterogeneous group of generally aggressive malignancies. They constitute approximately $15 \%$ of all non-Hodgkin lymphomas (NHLs) in adults ${ }^{1,2}$. The most common subtype of PTCL is PTCL, not otherwise specified (PTCL, NOS). It accounts for approximately $30 \%$ of PTCL and approximately $4 \%$ of $\mathrm{NHL}^{3}$. The other subtypes of PTCL are anaplastic large cell lymphoma (ALCL), angioimmunoblastic $\mathrm{T}$ cell Iymphoma (AITCL), extranodal natural killer (NK)/T cell lymphoma, subcutaneous panniculitis-like T cell lymphoma, enteropathy associated T cell Iymphoma, and hepatosplenic T cell lymphoma ${ }^{2,3}$. PTCL, NOS is derived from mature T cells ${ }^{2}$. Patients should be classified in this group if they do not meet the criteria for the other specifically defined subtypes of $\mathrm{PTCL}^{2}$. The median age at diagnosis is 60 years and there is a male predominance ${ }^{4,5}$.

In general, with combination chemotherapy, the 5-year overall survival (OS) has been reported between 49\% and 74\% among PTCL patients with low or low-intermediate International Prognostic Index (IPI) scores, respectively ${ }^{6}$. On the other hand, the 5-year OS with combination chemotherapy has been reported to be between $6 \%$ and 21\% among patients with high-intermediate or high IPI scores, respectively ${ }^{6}$. Recent studies have confirmed that, except for anaplastic lymphoma kinase (ALK) positive ALCL, most of the PTCL subtypes have a worse prognosis than most B-cell NHL subtypes ${ }^{6}$. Combination chemotherapy such as cyclophosphamide, doxorubicin, vincristine, and prednisone (CHOP) or similar are associated with low response rates and short duration of response in the majority of patients with $\mathrm{PTCL}^{7}$.

The poor outcomes with combination chemotherapy have led to an interest in more aggressive strategies such as the role and the timing of autologous hematopoietic stem cell transplantation (ASCT). ASCT is used as consolidation therapy in patients with PTCL, who have a chemosensitive response after induction or salvage therapy. However, the precise role of upfront ASCT remains largely unknown. PTCL is a rare hematological malignancy; therefore, the number of prospective randomized studies and patients enrolled in the studies are limited. In this study, we aimed to analyze the outcome of PTCL patients who underwent ASCT at our center and we researched whether first complete remission (CR) was the optimal timing for ASCT in patients with PTCL.

\section{MATERIALS AND METHODS}

The data of PTCL patients who underwent ASCT between January 2010 and December 2020 at Üniversity of Health Sicences Turkey, Dr. Abdurrahman Yurtaslan Ankara Oncology Training and Research Hospital, Department of Bone Marrow Transplantation Center were retrospectively analyzed. The subtypes of PTCL including PTCL NOS, ALCL, AITCL, and extranodal NK/T cell lymphoma were included. The data about the age, gender, Ann Arbor stage, initial treatment and response to first-line treatment, disease response before ASCT, conditioning regimens patients received before ASCT, progression-free survival (PFS), and OS after ASCT were analyzed. ${ }^{18} \mathrm{~F}$ - fluorodeoxyglucose positron emission tomography imaging was performed in all patients at the time of diagnosis, at the end of chemotherapy, and in the third month of ASCT to evaluate the response. The Lugano Modification of Ann Arbor Staging 2014 criteria were used for assessing response after chemotherapy and $\mathrm{ASCT}^{8}$. At our center, the patients who achieved CR1 after first-line treatment underwent ASCT for upfront consolidation. The patients who had residual disease after induction were administered a salvage treatment and after that, they underwent ASCT.

Among ASCT, the engraftment definition for neutrophil was defined as the first day when the absolute neutrophil count was $>500 / \mathrm{mm}^{3}$ or $1000 / \mathrm{mm}^{3}$ for three consecutive days, and thrombocyte engraftment was defined as the first day when thrombocyte count was $>20000 / \mathrm{mm}^{3}$ for three consecutive days without transfusion. All patients received weight-adapted G-CSF before the neutrophil engraftment. OS was calculated from the date of ASCT to death or the last date of follow-up. PFS was calculated from the date of ASCT to disease progress, death, or date of the latest follow-up for progression-free patients, whichever occurred first. Transplantation-related mortality (TRM) was defined as death within the first 100 days after ASCT $^{9}$.

The study were approved by the Üniversity of Health Sicences Turkey, Dr. Abdurrahman Yurtaslan Ankara Oncology Training and Research Hospital of Local Ethics Committee (protocol number: 2020-12/909, date: 09.12.2020).

All procedures performed in the study, involving human participants, were in accordance with the national research committee's ethical standards and with the 1964 Helsinki Declaration and its later amendments or comparable ethical standards. 


\section{Statistical Analysis}

All statistical analyses were conducted using Statistical Package for the Social Sciences (SPSS) V21.0 (SPSS Inc., Chicago, IL) software. Descriptive statistics were applied to summarize the data. The categorical data were reported as rates, and numeric data were reported as medians and average \pm standard deviations. The Kaplan-Meier test was used to analyze PFS and OS.

\section{RESULTS}

In total, there were 25 patients with PTCL who underwent ASCT. The median age at the time of ASCT among all patients was 44 years (range: 19-68). The male-to-female ratio was 19/6. 17 patients (68\%) were performed upfront ASCT after the first CR whereas $8(32 \%)$ patients were performed ASCT after relapse or refractory $(R / R)$ disease. $13(52 \%)$ patients were PTCL NOS; 8 (32\%) patients were ALK-negative ALCL, and 3 (12\%) patients were AITCL, and one (4\%) patient was extranodal $\mathrm{NK} / \mathrm{T}$ cell lymphoma. Most of the patients (76\%) were at advanced stage (Stage 3-4) at the diagnosis. Thirteen patients had CHOP (Cyclophosphamide, daunorubicin, vincristine, prednisone); eight patients had CHOEP (cyclophosphamide, daunorubicin, vincristine, prednisone, etoposide), two patients had HYPERCVAD (cyclophosphamide, vincristine, doxorubicin, dexamethasone alternating with high-dose methotrexate and cytarabine), one patient had EPOCH (etoposide, prednisone, vincristine, cyclophosphamide, doxorubicin), one patient had SMILE (dexamethasone, methotrexate, ifosfamide asparaginase, etoposide) for induction regimen. The characteristics of the patients are given in Table 1 . When we evaluated the response to the induction regimen, the overall response rate (ORR) was $88 \%$ among the patients, $12 \%$ of patients were refractory after induction chemotherapy.

Before ASCT, of the patients, 17 (68\%) were in CR1, four (16\%) patients were in CR2, four (16\%) patients were in partial remission ( $P R$ ). In the $R / R$ patients, five patients received two lines of salvage therapy and three patients had one salvage treatment before ASCT. Twenty-one (84\%) patients received BEAM (carmustine, cytarabine, melphalan, etoposide), and three (12\%) patients received ICE (carboplatin, ifosfamide, etoposide), and one (4\%) patient received BuCyE (busulfan, cyclophosphamide, and etoposide) as conditioning regimen. The median time to transplantation was 12 months (range: 6-36 months). Except for one patient, the patients received mobilized peripheral blood as the stem-cell source, one patient harvested for bone marrow stem-cell source. The median neutrophil engraftment duration was 11 (range: 9-18) days, and the median platelet engraftment was 15 (range: 8-19) days. Twenty (80\%) patients achieved CR and four (16\%) patients had progressive disease three months after ASCT; one patient was not evaluated due to being exitus in the first month of the transplantation. The median follow-up time from diagnosis was 40 months (13-144 months).
After a median follow up of 25 months (range: 1-129 months) from ASCT, two (25\%) patients were alive among patients who underwent ASCT after R/R disease; on the other hand, 14 (\%82) patients were alive among patients who underwent upfront ASCT after first CR.

The five-year PFS and OS were 50.8\% and 55.7\%, respectively. The median of both PFS and OS was not reached. When we evaluated considering patients who underwent upfront ASCT consolidation, OS was significantly longer among the upfront

\section{Table 1. Characteristics of the patients}

\begin{tabular}{|c|c|}
\hline Patients (n) & 25 \\
\hline Age (median) & 44 years $(19-68)$ \\
\hline Gender (M/F) & $19 / 6$ \\
\hline $\begin{array}{l}\text { Ann Arbor stage } \\
\text { (Lugano 2014) }\end{array}$ & $\begin{array}{l}\text { Stage 1-2: } 3(12 \%) \\
\text { Stage 3-4: } 19(76 \%) \\
\text { Unknown: } 3(12 \%)\end{array}$ \\
\hline Lymphoma subtype & $\begin{array}{l}\text { PTCL, NOS: } 13(52 \%) \\
\text { ALCL: } 8(32 \%) \\
\text { AITCL: } 3(12 \%) \\
\text { Ekstranodal/NK-T cell: } 1(4 \%)\end{array}$ \\
\hline Initial treatment & $\begin{array}{l}\text { CHOP: } 13(52 \%) \\
\text { CHOEP: } 8(32 \%) \\
\text { HYPERCVAD: } 2(8 \%) \\
\text { EPOCH: } 1(4 \%) \\
\text { SMILE: } 1(4 \%)\end{array}$ \\
\hline $\begin{array}{l}\text { Pre-ASCT disease } \\
\text { response }\end{array}$ & $\begin{array}{l}\text { CR1: } 17(68 \%) \\
\text { CR2: } 4(16 \%) \\
\text { PR: } 4(16 \%)\end{array}$ \\
\hline Conditioning & $\begin{array}{l}\text { BEAM: } 21(84 \%) \\
\text { ICE: } 3(12 \%) \\
\text { BuCyE: } 1(4 \%)\end{array}$ \\
\hline Response after ASCT & $\begin{array}{l}\text { CR: } 20(80 \%) \\
\text { Progression: } 4(16 \%) \\
\text { Not evaluated: } 1(4 \%)\end{array}$ \\
\hline $\begin{array}{l}\text { Transplantation-related } \\
\text { mortality }\end{array}$ & $1(4 \%)$ \\
\hline $\begin{array}{l}\text { Neutrophil } \\
\text { engraftment duration } \\
\text { (median) }\end{array}$ & 11 days (range: 9-18) \\
\hline $\begin{array}{l}\text { Platelet engraftment } \\
\text { duration (median) }\end{array}$ & 15 days (range: $8-19$ ) \\
\hline $\begin{array}{l}\text { Quantity of CD34+ } \\
\text { infused (median) }\end{array}$ & $4.8 \times 10^{6} / \mathrm{kg}$ (range: $\left.3.5 \times 10^{6} / \mathrm{kg}-11.4 \times 10^{6} / \mathrm{kg}\right)$ \\
\hline
\end{tabular}

AITCL: Angioimmunoblastic T cell lymphoma, ALCL: Anaplastic large cell lymphoma, ASCT: Autologous hematopoietic cell transplantation, BEAM, BCNU: Etoposide, cytarabine and melphalan, BuCyE: Busulfan, cyclophosphamide and etoposide, CHOP: Cyclophosphamide, daunorubicin, vincristine, prednisone, CHOEP: Cyclophosphamide, daunorubicin, vincristine, prednisone, etoposide, CR: Complete response, ECOG: Eastern Cooperative Oncology Group, EPOCH: Etoposide, prednisone, vincristine, cyclophosphamide, doxorubicin, F: Female, IPI: International prognostic index, HYPERCVAD: Cyclophosphamide, vincristine, doxorubicin, dexamethasone alternating with high-dose methotrexate and cytarabine, ICE: Ifosfamide, carboplatin, etoposide, M: Male, PR: Partial response, PTCL-NOS: Peripheral T cell lymphoma, not otherwise specified, SMILE: Dexamethasone, methotrexate, ifosfamide asparaginase, etoposide 
ASCT group. These patients' five-year OS was $82.4 \%$, while the five-year OS for the patients who underwent ASCT after R/R disease was $15.6 \%(p=0.019)$. In the $R / R$ patients, the median

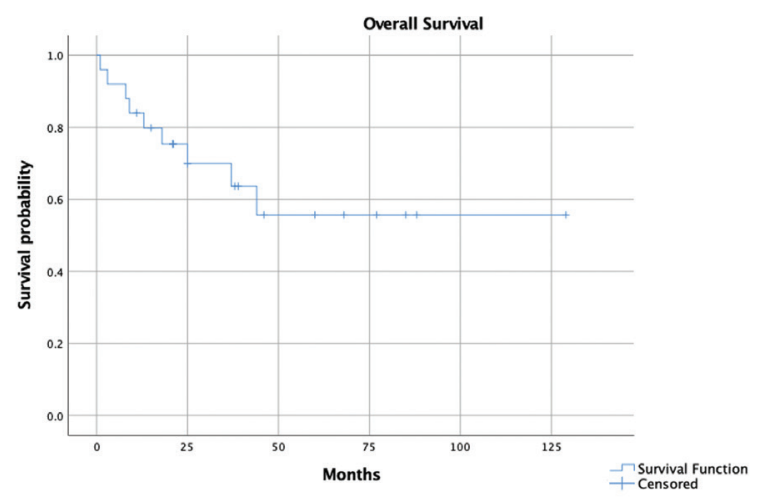

Figure 1. Overall survival

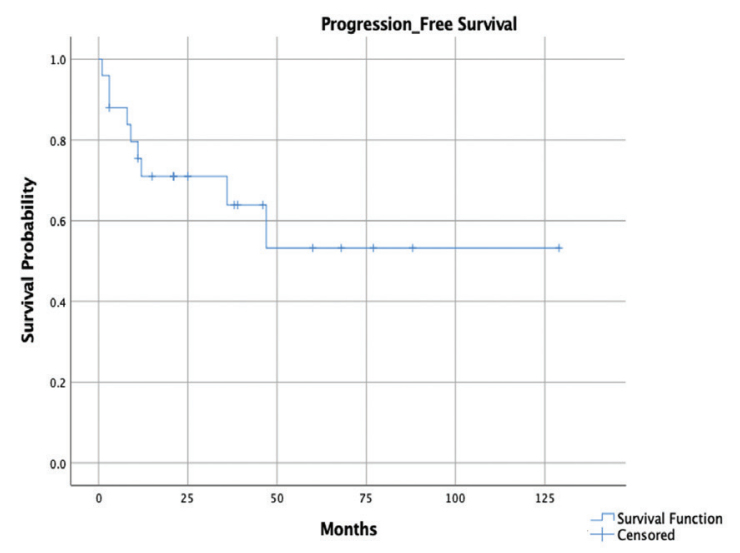

Figure 2. Progression free survival

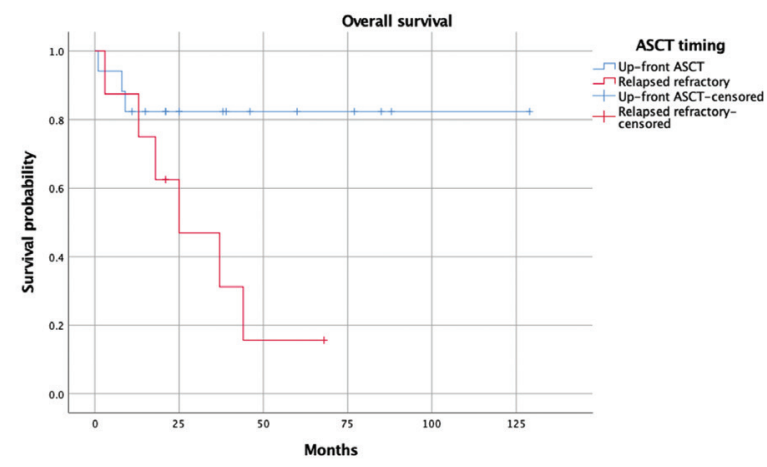

Figure 3. Overall survival according to autologous stem cell transplantation timing

ASCT: Autologous stem cell transplantation

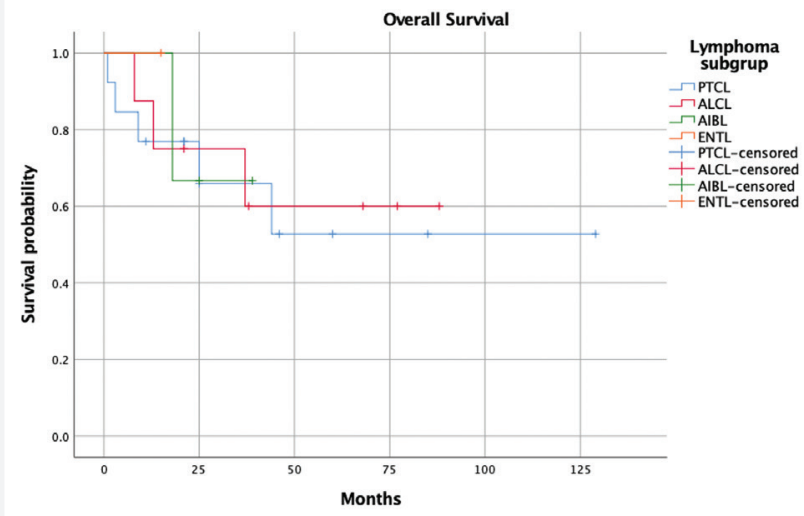

Figure 4. Overall survival according to lymphoma subtype

ASCT: Autologous stem cell transplantation, PTCL: Peripheral T cell lymphomas not otherwise specified, ALCL: Anaplastic large cell lymphoma, AIBL: Angioimmunoblastic T cell lymphoma, ENTL: Extranodal natural killer/T cell lymphoma

OS was 25 months (95\% Cl: 2.7-47.2), the median PFS was 12 months [95\% confidence interval (CI): 1-41.6] after ASCT. However, the median OS and PFS were not reached in the upfront ASCT group. The median OS was 25 months $(95 \% \mathrm{Cl}$ : 0-50.4) in patients who had CR2 response before ASCT, while it was 13 months (95\% Cl: 0-35) in patients who had PR before ASCT ( $p=0.03$ ). According to the subtypes of PTCL, OS and PFS were not statistically different in all patients $(p=0.96$ and $p=0.79$, respectively). The survival curves are given in Figures 1-4. TRM was observed in one patient (due to sepsis).

\section{DISCUSSION}

We analyzed the outcome of PTCL patients who underwent ASCT at our center in the current study. We observed that first CR was the optimal timing for ASCT in patients with PTCL. OS was significantly longer among the patients who underwent ASCT in the up-front setting in first CR rather than CR2 or PR response.

Previous studies have demonstrated that most of the PTCL subtypes have a poorer prognosis than most of the B-cell NHL subtypes ${ }^{4-6}$. Currently, CHOP or CHOP-like combination chemotherapies are the standard first-line treatment approaches for PTCLs. However, except for ALK-positive ALCL, the outcome for most patients with PTCL remains dismal, with low response rates and short durations of remission ${ }^{10}$.

Savage et al. conducted a study on 199 patients with PTCL and they reported that 5-year OS of patients with PTCL/NOS, ALCL, and AILT was between 35\% and 43\% with CHOP or CHOP-like chemotherapy ${ }^{11}$. Vose et al. ${ }^{4}$ reported that the 5-year failurefree survival and OS of patients with PTCL-NOS, ALK-positive ALCL, ALK-negative ALCL, and AITL were 20\% and 32\%, 60\% 
and $70 \%, 36 \%$, and $49 \%$, and $18 \%$ and $32 \%$, respectively.

In the last years, studies have been conducted to evaluate the role of upfront ASCT in patients with PTCL. However, as it is not a common disease, the number of patients enrolled in these studies is limited. In the prospective study by the Nordic Lymphoma Group, ASCT was performed on 115 patients with PTCL after 6 cycles of CHOEP. The TRM was $1.7 \%$ and 5 -year OS for patients with ALCL, AILT, and PTCL-NOS was 70\%, 52\%, and $47 \%$, respectively ${ }^{12}$. Reimer et al. ${ }^{13}$ reported the outcome of 83 patients with PTCL (excluding ALK-positive ALCL) after induction with CHOP. In their study, patients received total body irradiation and high-dose cyclophosphamide as a conditioning regimen. Only one patient died due to TRM. They found that the median time to relapse following ASCT was 11.5 months and 3 -year OS was $48 \%$. In the study conducted by Chen et al. ${ }^{14}$, in which they evaluated the outcome of 53 PTCL patients who were performed ASCT, they reported a 5-year PFS and OS as 25\% and $48 \%$ among all patients. In the same study, the 5-year PFS and OS were $51 \%$ and $76 \%$ in patients who underwent ASCT in the first remission. In another study, the 5 year OS was $80 \%$ in patients who underwent ASCT in CR1 and it was 50\% in patients who underwent ASCT in CR2 ${ }^{15}$. In the study by Blystad et al. ${ }^{16}$, in which researchers evaluated the outcome of 40 patients with PTCL, TRM was $7.5 \%$, and the 3-year event-free survival and OS were $48 \%$ and $58 \%$, respectively. In this study, 11 patients were transplanted at CR1 following induction therapy. In a previous study, Ahn et al. ${ }^{17}$ demonstrated the outcome of 31 patients with PTCL who underwent upfront ASCT after initial induction chemotherapy and the patients received BuCyE as conditioning regimen ${ }^{17}$. Before ASCT, 23 patients (74.2\%) had CR and 8 patients (25.8\%) had PR. At a median follow-up of 32.4 months, the 3 -year estimated OS and PFS was $64.5 \pm 8.6 \%$ and TRM was $9.7 \%$.

In our study, the characteristics of the patients were similar to previous studies. Nearly three-quarters of the patients had the advanced stage at diagnosis. Most of the patients received CHOP-based induction and 68\% of the patients underwent up-front ASCT. After a median follow-up of 25 months from ASCT, 82\% patients were alive among patients who underwent upfront ASCT after first $C R$, while $25 \%$ of $R / R$ patients were alive in the R/R group. We showed that five-year PFS and OS were $50.8 \%$ and $55.7 \%$ in our cohort, respectively. Among the upfront ASCT group, five-year OS was $82.4 \%$, while it was $15.6 \%$ in the R/R group. Our study showed that a significantly longer survival advantage was observed for the PTCL patients by upfront ASCT. Compared to the pre-ASCT responses, the worst survival was seen in the patients who had PR responses before ASCT. Differently, we did not observe survival differences according to lymphoma subtypes.

\section{Study Limitations}

The retrospective design of the study and the low number of patients included in our study were our limitations. The variation of the first-line treatment regimens and also ASCT conditioning regimens depending on the clinician's preference was another limiting factor. Randomized-controlled and prospective studies with extended-patients should be conducted to prove the hypothesis.

\section{CONCLUSION}

As a result, upfront ASCT is the optimal time for PTCL patients in first CR. The five-year OS was $82.4 \%$ in our study. According to our results, the pre-ASCT response is an important and predictive factor for the patients. If the patients could achieve CR1, ASCT may provide a survival advantage rather than CR2 or PR.

Since the remission durations are short with $\mathrm{CHOP}$ and $\mathrm{CHOP}-$ like chemotherapies and the prognosis is poor in patients with PTCL, the patients should be consolidated with ASCT in the first $\mathrm{CR}$, and relapse should not be waited to perform ASCT.

\section{Acknowledgement}

We would like to thank our nurses Gül Ören Kulkul and İclal Uçar for their assistance and support in data acquisition.

\section{Ethics}

Ethics Committee Approval: The study were approved by the Üniversity of Health Sicences Turkey, Dr. Abdurrahman Yurtaslan Ankara Oncology Training and Research Hospital of Local Ethics Committee (protocol number: 2020-12/909, date: 09.12.2020).

Informed Consent: Consent form was filled out by all participants.

Peer-review: Externally peer-reviewed.

\section{Authorship Contributions}

Surgical and Medical Practices: M.K.Ç., M.S.D., F.A., Concept: M.K.Ç., M.S.D., Design: T.N.Y., F.A., Data Collection or Processing: D.Ş., B.U.U., Analysis or Interpretation: B.U.U., F.A., Literature Search: T.N.Y., Writing: B.U.U.

Conflict of Interest: No conflict of interest was declared by the authors.

Financial Disclosure: The authors declared that this study received no financial support.

\section{References}

1. World Health Organization Classification of Tumours of Haematopoietic and Lymphoid Tissues, Swerdlow SH, Campo E, Harris NL, et al. (Eds), IARC 


\section{Press, Lyon 2008.}

2. Swerdlow SH, Campo E, Pileri SA, Harris NL, Stein H, Siebert R, et al. The 2016 revision of the World Health Organization classification of lymphoid neoplasms. Blood. 2016;127:2375-90.

3. Morton LM, Wang SS, Devesa SS, Hartge P, Weisenburger DD, Linet MS. Lymphoma incidence patterns by WHO subtype in the United States, 1992-2001. Blood. 2006;107:265-76.

4. Vose J, Armitage J, Weisenburger D; International T-Cell Lymphoma Project. International peripheral T-cell and natural killer/T-cell lymphoma study: pathology findings and clinical outcomes. J Clin Oncol. 2008;26:4124-30.

5. Weisenburger DD, Savage KJ, Harris NL, Gascoyne RD, Jaffe ES, MacLennan $K A$, et al. Peripheral T-cell lymphoma, not otherwise specified: a report of 340 cases from the International Peripheral T-cell Lymphoma Project. Blood. 2011;117:3402-8.

6. Sonnen R, Schmidt WP, Müller-Hermelink HK, Schmitz N. The International Prognostic Index determines the outcome of patients with nodal mature T-cell lymphomas. Br J Haematol. 2005;129:366-72.

7. Moskowitz AJ, Lunning MA, Horwitz SM. How I treat the peripheral T-cell lymphomas. Blood. 2014;123:2636-44.

8. Van Heertum RL, Scarimbolo R, Wolodzko JG, Klencke B, Messmann R, Tunc

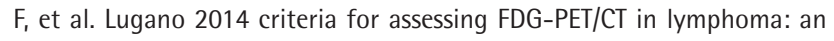
operational approach for clinical trials. Drug Des Devel Ther. 2017;11:171928.

9. Davies SM, Kollman C, Anasetti C, Antin JH, Gajewski J, Casper JT, et al. Engraftment and survival after unrelated-donor bone marrow transplantation: a report from the national marrow donor program. Blood. 2000;96:4096-102.
10. Armitage J0. The aggressive peripheral T-cell lymphomas: 2015. Am J Hematol. 2015;90:665-73.

11. Savage KJ, Chhanabhai M, Gascoyne RD, Connors JM. Characterization of peripheral T-cell lymphomas in a single North American institution by the WHO classification. Ann Oncol. 2004;15:1467-75.

12. d'Amore $F$, Relander $T$, Lauritzsen $G F$, Jantunen $E$, Hagberg $H$, Anderson $H$ et al. Up-front autologous stem-cell transplantation in peripheral T-cell Iymphoma: NLG-T-01. J Clin Oncol. 2012;30:3093-9.

13. Reimer $P$, Rüdiger $T$, Geissinger $E$, Weissinger $F$, Nerl $C$, Schmitz N, et al. Autologous stem-cell transplantation as first-line therapy in peripheral T-cell lymphomas: results of a prospective multicenter study. J Clin Oncol. 2009;27:106-13.

14. Chen Al, McMillan A, Negrin RS, Horning SJ, Laport GG. Long-term results of autologous hematopoietic cell transplantation for peripheral T cell lymphoma: the Stanford experience. Biol Blood Marrow Transplant. 2008;14:741-7.

15. Rodríguez J, Caballero MD, Gutiérrez A, Marin J, Lahuerta JJ, Sureda A, et al. High-dose chemotherapy and autologous stem cell transplantation in peripheral T-cell lymphoma: the GEL-TAMO experience. Ann Oncol. 2003;14:1768-75.

16. Blystad AK, Enblad G, Kvaløy S, Berglund A, Delabie J, Holte H, et al. Highdose therapy with autologous stem cell transplantation in patients with peripheral T cell lymphomas. Bone Marrow Transplant. 2001;27:711-6.

17. Ahn JS, Yang DH, Jung SH, Chae YS, Sohn SK, Yhim HY, et al. Autologous stem cell transplantation with busulfan, cyclophosphamide, and etoposide as an intensifying frontline treatment in patients with peripheral T cell lymphomas: a multicenter retrospective trial. Ann Hematol. 2013;92:78997. 